\title{
Feasibility of using photovoltaic solar energy for water treatment plants
}

\author{
Alexander Saavedra ${ }^{1}$, Nataly Alejandra Galvis ${ }^{2}$, Mónica Castaneda ${ }^{3}$, Sebastian Zapata ${ }^{4}$, \\ Fredy Mesa $^{5}$, Andrés Julián Aristizábal ${ }^{6}$ \\ 1,2,3,4,6 Universidad de Bogotá Jorge Tadeo Lozano, Engineering Department, EADE Group, Bogotá, Colombia \\ ${ }^{5}$ Universidad del Rosario, Faculty of Natural Sciences, NanoTech Group, Bogotá, Colombia
}

\begin{tabular}{l} 
Article Info \\
\hline Article history: \\
Received Jul 28, 2020 \\
Revised Dec 9, 2020 \\
Accepted Dec 21, 2020 \\
\hline
\end{tabular}

\section{Keywords:}

Drinking water

Photovoltaic systems

Renewable energy

Solar energy

Water treatment plants

\begin{abstract}
The purpose of this research is to determine the feasibility of supplying photovoltaic solar energy for the electrical requirements of drinking water and wastewater treatment plants, in six regions of Colombia, with different geographic and climatological conditions: Andean Region, Amazon Region, Orinoquía Region, Caribbean Region, Pacific Region, and Insular Region. The study revealed that the costs of the photovoltaic systems oscillate between USD 32,486.86 and USD 40,716.86, without using a storage system with batteries, since the price of these makes the investment recovery unfeasible. Instead of using batteries to store energy, a water storage system is used. The total daily load of the sanitation systems is $57 \mathrm{kWh} /$ day, which would avoid $7120.44 \mathrm{~kg} \mathrm{CO} 2$ per year. Besides, during the entire useful life of the 20-year project, $142.4 \mathrm{tCO} 2$ would not be released into the environment.
\end{abstract}

This is an open access article under the CC BY-SA license.

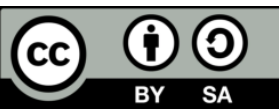

\section{Corresponding Author:}

Fredy Mesa

Faculty of Natural Sciences

Universidad del Rosario

Cra. 24 \#63C-69, Bogotá, Colombia

Email: fredy.mesa@urosario.edu.co

\section{INTRODUCTION}

The basis of life in any of its forms is water, and the scarcity of this resource affects the communities' social and economic development. Studies that cover the renewable energy generation, integrating the entire cycle of purification and wastewater treatment, are a necessity for social welfare and environmental care. The energy generated by photovoltaic solar panels represents an excellent option to bring electricity to rural communities that do not have a conventional electricity grid to provide their primary services [1]. Water pumping systems that use photovoltaic solar panels to supply electricity have become a proper implementation of communities' water supply $[2,3]$. There are several advantages of water pumping systems using solar energy: the use of photovoltaic panels does not generate greenhouse gas emissions [4], practically no maintenance is required [5], and its costs are competitive in rural areas, which are not interconnected to the electrical grid $[6,7]$.

Since the 1990s, water pollution has increased in almost all rivers in Latin America, Africa, and Asia, creating threats to human health, the environment, and sustainable development. Different studies demonstrate the versatility of using photovoltaic solar energy in the electromechanical systems required to supply water to remote sites or that do not have the appropriate conditions to obtain it, and that also implement innovative systems and methods to make it drinkable [8-18]. To provide good quality water to urban populations, raw water must be treated in drinking water treatment plants, which are energy-intensive facilities where energy intensity depends on water treatment technology [19]. In turn, there are different types of wastewater treatment 
plants with various technologies due to the quality and flow rate of the wastewater to be treated [20]. Many studies have been devoted to investigating the performance and modeling of solar energy systems [21-27]. However, in Colombia, it is required more research on issues related to the economic analysis of photovoltaic solar energy systems in water treatment plants for isolated communities.

\section{METHODOLOGY}

This proposal considers the need to implement water treatment systems efficiently in any area of the country, areas with technical and economic limitations that restrict access to drinking water, and to an adequate treatment of wastewater under current regulations. Figure 1 shows the simplified scheme of an integral basic sanitation system, which begins with the intake and the adduction line.

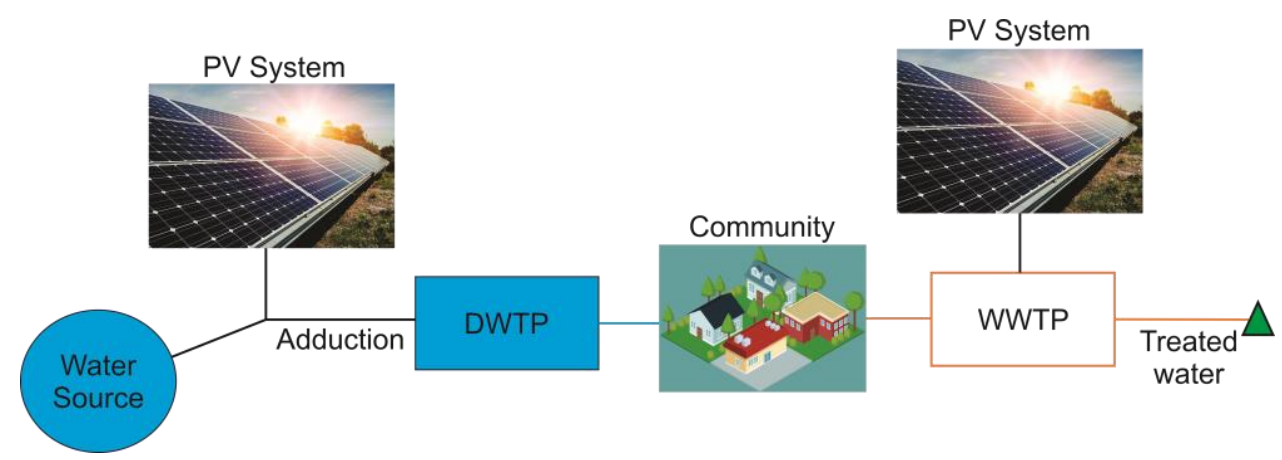

Figure 1. Scheme of a comprehensive water treatment system (source: own elaboration)

In general, and for the case of this study, this system requires electromechanical equipment for its operation, such as electro pumps and hydro pneumatics. This equipment is followed by the drinking water treatment plant (DWTP), which treats the water with the aim of being used in daily activities safely. After the wastewater is generated, it is taken through sewers to the wastewater treatment plant (WWTP) to remove pollutants and generate a less environmental impact on the source that receives these waters.

The entire chain in the integral water treatment system requires electrical energy to carry out the processes described above. For this, the use of photovoltaic (PV) energy to supply electricity to the water treatment plants, equipment, and structures necessary for its proper operation is proposed. The selected municipalities are representative of the six regions of the country: Andean Region, Amazon Region, Orinoquía Region, Caribbean Region, Pacific Region and Insular Region (Table 1 show these data are related to global horizontal irradiation (GHI)) and took into account the ease of transportation and maintenance of the water treatment and solar panels, difficulties in energy and water coverage, the need for the project in the community and the ecosystem benefits of reducing the environmental impact in the area.

The data used for this study are the drinking water and the wastewater treatment requirements for a community of 100 people. The maximum amount of water for one person per day will be taken, plus a percentage of losses according to current Colombian regulations. From this data, the residual water flow is calculated with a return coefficient of $0.85 \%$, and the design flow of the water treatment plants is known. Figure 2 shows the main components for water purification.

Design data such as the height difference between the water reservoir and the DWTP are assumed. It is also stipulated that the height difference between the DWTP and the community is 0 m.a.s.l., and a pressure of $20 \mathrm{~m}$ of water column (m.w.c) will be guaranteed. The design flow of drinking water considers a provision of $140 \mathrm{l}$ /day per person plus $25 \%$ of losses. Also, the design flow increases since the treatment plant will only work 8 hours per day. With this operating time, the operation of the integrated DWTP system is guaranteed during the hours of sunlight available without the need for batteries. In the case of using electric pumps, fatigue will be avoided in the equipment. A system is required for the collection and delivery of water to the DWTP, which will consist of two 1 HP solar electric pumps protected from the weather in a booth. With this system, the electric pumps rotate, and there are no energy losses. After the water enters the DWTP, it is stored in water tanks and must be pushed until it reaches the community. For this purpose, another discharge booth is installed with two $2 \mathrm{HP}$ solar pumps to handle a flow of $3 \mathrm{l} / \mathrm{s}$. The consumptions and hourly uses to determine the total load in DC are presented in Table 2. Figure 3 shows the schematic of the activated sludge wastewater treatment plant. 
Table 1. Selected municipalities for the research (source: authors and NASA data)

\begin{tabular}{ccccc}
\hline Municipality & \multicolumn{2}{c}{ Coordinates } & $\begin{array}{c}\text { Solar Radiation } \\
(\mathrm{kWh} / \mathrm{m} 2 / \text { day })\end{array}$ & $\begin{array}{c}\text { Temperature } \\
\text { Max-Prom }\end{array}$ \\
\hline Leticia & -4.2081 & -69.9432 & 4.58 & $31^{\circ} \mathrm{C}-26^{\circ} \mathrm{C}$ \\
Providencia & 3.0880 & -73.2500 .0 & 5.74 & $28^{\circ} \mathrm{C}-27^{\circ} \mathrm{C}$ \\
Uribia & 11.7139 & -72.2660 .4 & 5.86 & $34^{\circ} \mathrm{C}-28^{\circ} \mathrm{C}$ \\
Puerto Carreño & 6.1890 & -67.4858 .8 & 5.22 & $36^{\circ} \mathrm{C}-27^{\circ} \mathrm{C}$ \\
Nuquí & 5.70694 & 77.2702 .77 & 3.95 & $32^{\circ} \mathrm{C}-25^{\circ} \mathrm{C}$ \\
Villa de Leyva & 5.633 & -73.533 & 5.04 & $24^{\circ} \mathrm{C}-17^{\circ} \mathrm{C}$ \\
\hline
\end{tabular}

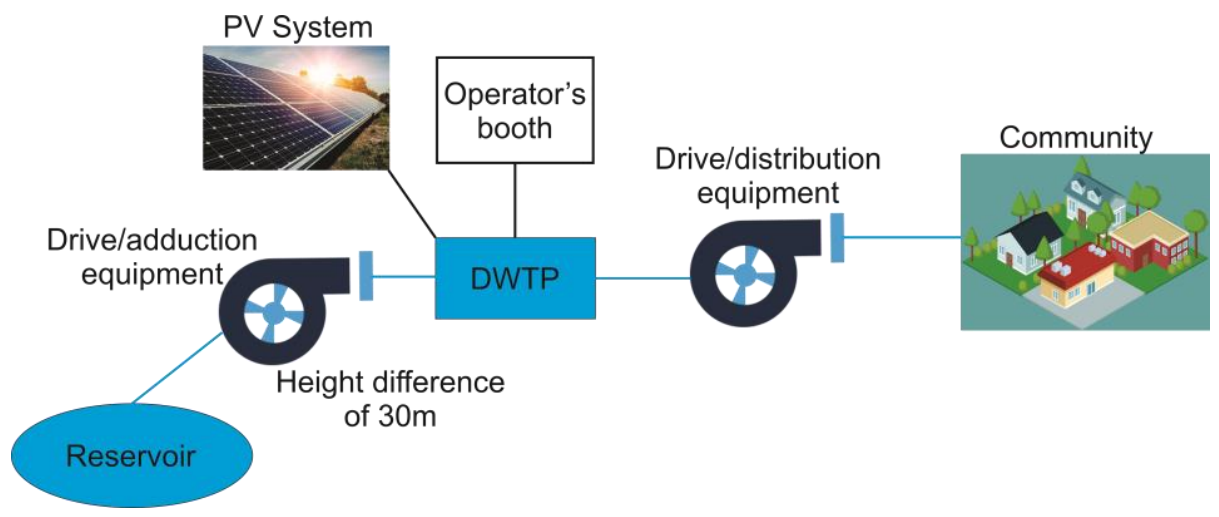

Figure 2. General diagram of the drinking water treatment plant (DWTP) (source: own elaboration)

Table 2. The energy demanded for the drinking water treatment plant (DWTP)

\begin{tabular}{ccccc}
\hline DC Equipment & Quantity & $\begin{array}{c}\text { Power Per Unit } \\
(\mathrm{W})\end{array}$ & $\begin{array}{c}\text { Hours of Daily Use Per } \\
\text { Unit }\end{array}$ & $\begin{array}{c}\text { Total Charge } \\
\text { (W*h/day) }\end{array}$ \\
\hline Lighting & 2 & 50 & 4 & 400 \\
Electrical outlets & 2 & 500 & 6 & 6000 \\
Electro pumps 2HP & 2 & 2000 & 4 & 16000 \\
Electro pumps 0.5 HP & 2 & 700 & 4 & 5600,0 \\
Refrigerator & 1 & 100 & 8 & 2400,0 \\
DWTP & 1 & 400 & TOTAL DAILY DC & 3200,0 \\
& & & CHARGE (W*h/day) & 33600,0 \\
\hline
\end{tabular}

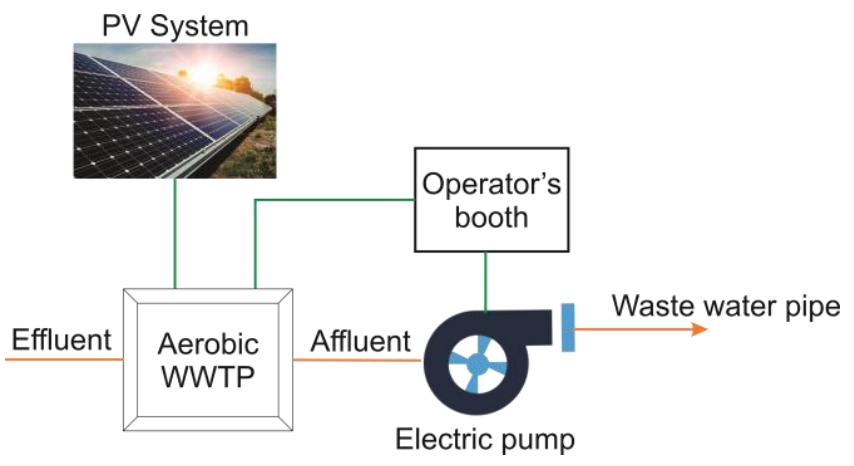

Figure 3. Wastewater treatment plant (WWTP) (source: own elaboration)

A treatment plant will be implemented with aerobic processes (activated sludge) running 24 hours a day for a flow rate of $0.5 \mathrm{l} / \mathrm{s}$. For the wastewater treatment system, the energy in Table 3 is required. With the energy demand required by the DWTP and by the WWTP, and with the solar radiation available at each installation site, the required photovoltaic systems are dimensioned. Subsequently, with the cost of energy for each municipality (Leticia \$ 0.35 USD/kWh; Providencia \$ 0.28 USD/kWh; Uribia \$ $0.15 \mathrm{USD} / \mathrm{kWh}$; Puerto Carreño \$ 0.17 USD/kWh; Nuquí \$ $0.34 \mathrm{USD} / \mathrm{kWh}$ and Villa de Leyva \$ $0.16 \mathrm{USD} / \mathrm{kWh}$ ) the return on economic investment is calculated. 
Table 3. Energy demanded for the waste water system (WWTP)

\begin{tabular}{ccccc}
\hline DC Equipment & Quantity & $\begin{array}{c}\text { Powet Per Unit } \\
\text { (W) }\end{array}$ & $\begin{array}{c}\text { Hours of Daily Use Per } \\
\text { Unit }\end{array}$ & $\begin{array}{c}\text { Total Charge } \\
\text { (W*h/Día) }\end{array}$ \\
\hline Lightings & 2 & 50 & 4 & 400 \\
Electrical outlets & 2 & 500 & 6 & 6000 \\
Refrigerator & 1 & 100 & 24 & 2400 \\
WWTP & 1 & 600 & 24 & 14400 \\
& & & TOTAL DAILY DC & 23200 \\
\hline
\end{tabular}

\section{RESULTS AND DISCUSSION}

Table 4 shows the results of the photovoltaic system classified among the number of panels and batteries for the drinking water system and the wastewater system by the municipality. According to the previous data, the numbers of photovoltaic modules for the municipalities of Nuquí and Leticia are the highest, with 150 panels and 129 panels respectively to cover the needs of the drinking and wastewater systems. The municipalities of Uribia and Providencia present the best solar radiation, and for this reason, 101 panels and 103 panels were obtained, respectively. Regarding the number of batteries, a standard behavior of 67 units is observed at all sites. Regarding to current national market information, a polycrystalline $400 \mathrm{~W}$ photovoltaic panel was chosen at USD 168.6 and a cost of 200 Ah gel batteries of USD 400. Figure 4 shows the cost of photovoltaic panels by municipality for drinking and waste water systems.

Table 4. Number of photovoltaic modules and batteries in the treatment systems

\begin{tabular}{ccccccc}
\hline Municipality & Leticia & Providencia & Uribia & Puerto Carreño & Nuquí & Villa de Leyva \\
\hline Quantity of PV panels for DWTP & 76 & 61 & 60 & 67 & 89 & 69 \\
Quantity of PV panels for WWTP & 53 & 42 & 41 & 46 & 61 & 48 \\
Total of PV panels & 129 & 103 & 101 & 28 & 150 & 117 \\
Quantity of batteries for DWTP & 28 & 28 & 28 & 28 & 28 & 28 \\
Quantity of batteries for WWTP & 39 & 39 & 39 & 39 & 39 & 67 \\
Total of batteries & 67 & 67 & 67 & 67 & 67 \\
\hline
\end{tabular}

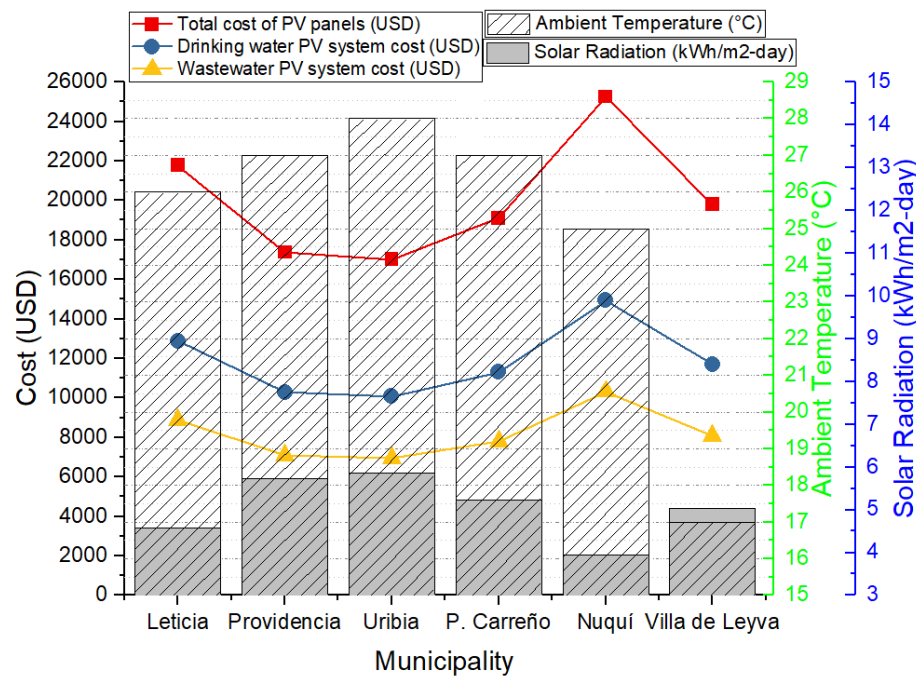

Figure 4. Cost by municipalities of PV modules for drinking and wastewater systems (source: own elaboration)

The municipality of Uribia in the department of La Guajira presents the lowest cost among the places evaluated with a total value of USD 17,020.16 for the system, followed by the island of Providencia in San Andrés, with a total cost of USD 17,375.97. The municipality with the highest investment cost in solar panels is Nuquí, with a price of USD 25,250.15. It is appreciated that the cost of solar panels is higher in the Drinking Water Treatment Plant, which is due to the pumping equipment provided in the supply and distribution system. Figure 5 shows the costs of the photovoltaic panels, including the energy storage system, with the batteries, for each region. 
As it is shown, the investment costs of the photovoltaic system with storage are between USD 43,686.85 and USD 51,916.85, with Uribia and Providencia as the municipalities where the least investment is required. The highest investment occurred in Nuquí and Leticia. The cost of the photovoltaic system with storage of drinking water and wastewater is leveled, taking into account the energy storage necessary for the operation of the activated sludge WWTP. Figure 6 shows the cost of the PV system, but without the battery storage system, for the potable water system for the 6 sites.

Without the batteries in the drinking water treatment plant, the total cost of the system decreases by USD 11,142.86. With this situation, investment costs would be between USD 32,486.86 and USD 40,716.86, which represent a considerable saving taking into account the size of the population and the change of batteries every 5 years. To calculate carbon dioxide emissions, an emission factor of $0.367 \mathrm{~kg} \mathrm{CO} 2 \mathrm{eq} / \mathrm{kWh}$ was used for Colombian electricity generation. The total daily charge of the sanitation systems is $57 \mathrm{kWh} /$ day; which means that $7120.44 \mathrm{~kg}$ of CO2 would be avoided per year and in the time that the 20 -year project lasts; the emission of $142.4 \mathrm{tCO} 2$ would not be emitted. The data presented above does not include installation costs. Table 5 shows the total cost of the drinking water system, including the installation of the photovoltaic system, considering a cost per installed $\mathrm{kW}$ of USD 857, which is an approximate value for Colombia.

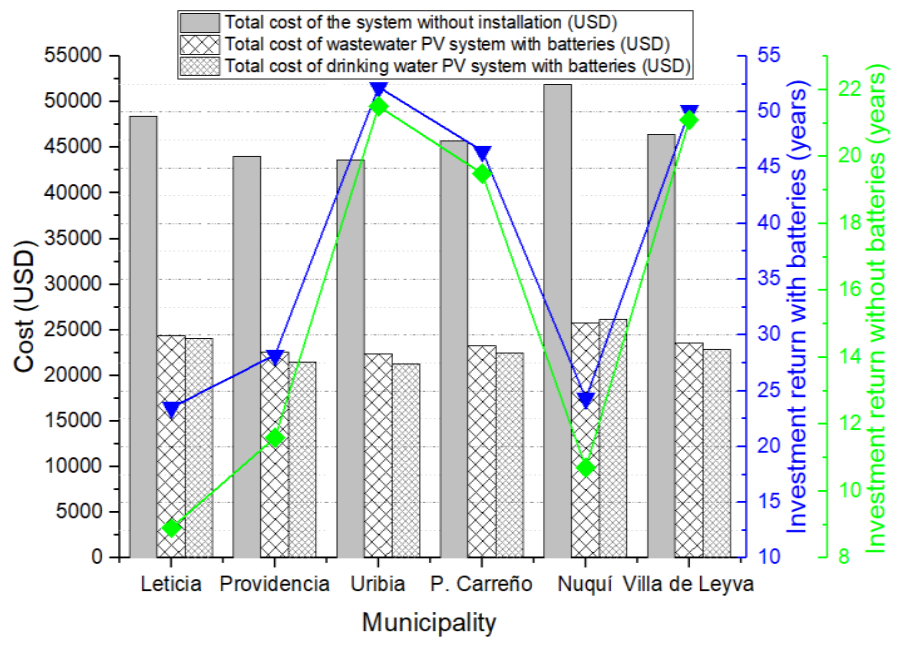

Figure 5. Cost by region of the PV panels with energy storage in the drinking and wastewater systems (source: own elaboration)

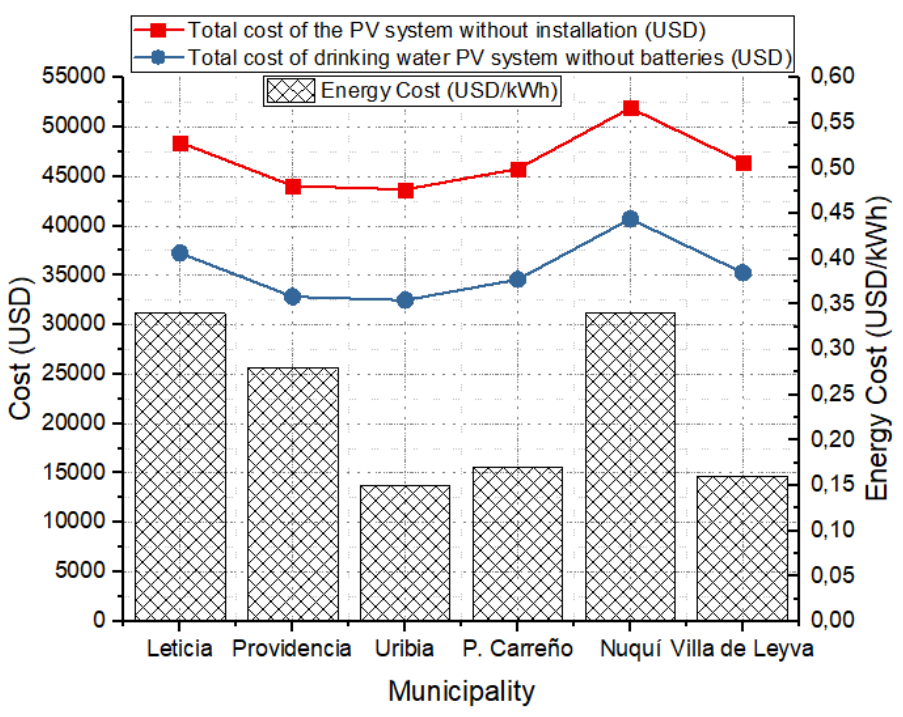

Figure 6. Cost of the PV system without energy storage, in the drinking water system for all sites (source: own elaboration) 
Table 5. Cost of the drinking water treatment plant with the installation of the photovoltaic system

\begin{tabular}{|c|c|c|c|c|c|c|c|c|c|}
\hline Municipality & $\begin{array}{c}\text { Energy } \\
\text { cost USD } \\
/ \mathrm{kWh}\end{array}$ & $\begin{array}{c}\text { KWh/ } \\
\text { day }\end{array}$ & $\begin{array}{l}\mathrm{kWh} / \\
\text { month }\end{array}$ & $\begin{array}{c}\text { Monthly } \\
\text { cost (USD) }\end{array}$ & $\begin{array}{l}\text { Annual cost } \\
\text { (USD) }\end{array}$ & $\begin{array}{c}\text { System cost } \\
\text { with } \\
\text { batteries } \\
\text { (USD) }\end{array}$ & $\begin{array}{c}\text { System cost } \\
\text { without } \\
\text { batteries } \\
\text { (USD) }\end{array}$ & $\begin{array}{c}\text { Investment } \\
\text { return with } \\
\text { batteries } \\
\text { (years) }\end{array}$ & $\begin{array}{l}\text { Investment } \\
\text { return without } \\
\text { batteries } \\
\text { (years) }\end{array}$ \\
\hline Providencia & 0.28 & 33.6 & 1008 & $\$ 282$ & $\$ 3,389$ & $\$ 95,422$ & $\$ 39,422$ & 28.2 & 11.6 \\
\hline Uribia & 0.15 & 33.6 & 1008 & $\$ 152$ & $\$ 1,824$ & $\$ 95,211$ & $\$ 39,211$ & 52.2 & 21.5 \\
\hline $\begin{array}{c}\text { Puerto } \\
\text { Carreño }\end{array}$ & 0.17 & 33.6 & 1008 & $\$ 173$ & $\$ 2,075$ & $\$ 96,446$ & $\$ 40,446$ & 46.5 & 19.5 \\
\hline $\begin{array}{l}\text { Villa de } \\
\text { Leyva }\end{array}$ & 0.16 & 33.6 & 1008 & $\$ 161$ & $\$ 1,932$ & $\$ 96,849$ & $\$ 40,849$ & 50.1 & 21.1 \\
\hline
\end{tabular}

As it is presented, by avoiding battery storage, the time of return on investment becomes feasible for any municipality in the country, with periods such as 8.9 years in Leticia, 10.7 years in Nuquí, and 11.6 years in Providencia. Even in the municipality of Uribia, with the cheapest cost per $\mathrm{kWh}$, the investment return is achieved at 21.5 years. For wastewater treatment and sanitation systems, considering the cost of installing photovoltaic systems; recovery times that exceed the useful life of photovoltaic systems are obtained, making the use of this technology unfeasible.

\section{CONCLUSION}

The municipalities with the best radiation levels are Uribia and Providencia with 5.86 and $5.71 \mathrm{kWh} / \mathrm{m} 2$-day, respectively. Villa de Leyva and Puerto Carreño also present excellent conditions for the development of photovoltaic projects with radiation exceeding $5 \mathrm{kWh} / \mathrm{m} 2$-day. At last, Leticia and Nuquí have radiation values of 4.58 and $3.95 \mathrm{kWh} / \mathrm{m} 2$-day. However, they are areas with high cloudiness and rainfall that further increase the costs of PV systems. In the municipalities of Providencia, Leticia, and Nuquí, diesel is currently used for energy generation, which increases the cost of energy and generates greenhouse gases and noise. With the proposed system for the treatment of drinking and wastewater, 7.1 tCO2 would be avoided annually, among other gases harmful to health and the environment.

The feasibility of implementing photovoltaic energy in wastewater treatment and purification systems is limited to the use of batteries, which only have a useful life that lasts about 5 years. The requirements of the drinking water system are more costly than those of the wastewater system as a result of the use of electric pumps. However, 24-hour battery storage for the activated sludge WWTP levels the investment cost in both treatments, even changing the batteries, the wastewater treatment costs rise to such a point that is not possible the initial return on investment.

\section{ACKNOWLEDGEMENTS}

The Universidad de Bogotá Jorge Tadeo Lozano (under Grant 830-15-17) and Universidad del Rosario supported this work.

\section{REFERENCES}

[1] L. Qoaider and D. Steinbrecht, "Photovoltaic systems: A cost competitive option to supply energy to off-grid agricultural communities in arid regions," Appl. Energy, vol. 87, no. 2, pp. 427-435, 2010.

[2] Y. Bakelli, A. Hadj Arab, and B. Azoui, "Optimal sizing of photovoltaic pumping system with water tank storage using LPSP concept,” Sol. Energy, vol. 85, no. 2, pp. 288-294, 2011.

[3] G. D. P. da Silva and M. H. Sharqawy, "Techno-economic analysis of low impact solar brackish water desalination system in the Brazilian Semiarid region," J. Clean. Prod., vol. 248, 2020.

[4] S. Ould-Amrouche, D. Rekioua, and A. Hamidat, "Modelling photovoltaic water pumping systems and evaluation of their CO2 emissions mitigation potential," Appl. Energy, vol. 87, no. 11, pp. 3451-3459, 2010.

[5] J. K. Kaldellis, E. Meidanis, and D. Zafirakis, "Experimental energy analysis of a stand-alone photovoltaic-based water pumping installation," Appl. Energy, vol. 88, no. 12, pp. 4556-4562, 2011.

[6] M. Al-Hrari, İ. Ceylan, K. Nakoa, and A. Ergün, "Concentrated photovoltaic and thermal system application for fresh water production,” Appl. Therm. Eng., vol. 171, no. July 2019, 2020.

[7] S. S. Chandel, M. Nagaraju Naik, and R. Chandel, "Review of solar photovoltaic water pumping system technology for irrigation and community drinking water supplies," Renew. Sustain. Energy Rev., vol. 49, pp. 1084-1099, 2015.

[8] N. Pichel, M. Vivar, M. Fuentes, and K. Eugenio-Cruz, "Study of a hybrid photovoltaic-photochemical technology for meeting the needs of safe drinking water and electricity in developing countries: First field trial in rural Mexico," J. Water Process Eng., vol. 33, Sep. 2020. 
[9] S. Kiwan, M. Al-Nimr, and I. Salim, "A hybrid solar chimney/photovoltaic thermal system for direct electric power production and water distillation," Sustain. Energy Technol. Assessments, vol. 38, Feb. 2020.

[10] H. Xu, X. Ji, L. Wang, J. Huang, J. Han, and Y. Wang, "Performance study on a small-scale photovoltaic electrodialysis system for desalination," Renew. Energy, vol. 154, pp. 1008-1013, 2020.

[11] S. Statkic, B. Jovanovic, A. Micic, N. Arsic, and S. Jović, "Adaptive neuro fuzzy selection of the most important factors for photovoltaic pumping system performance prediction," J. Build. Eng., vol. 30, no. July 2019, pp. 1-6, 2020.

[12] T. Vezin et al., "Borehole water level model for photovoltaic water pumping systems," Appl. Energy, vol. 258, Jul. 2020.

[13] J. Dai et al., "Design and construction of floating modular photovoltaic system for water reservoirs," Energy, vol. 191, 2020.

[14] R. J. Chilundo, G. A. Maúre, and U. S. Mahanjane, "Dynamic mathematical model design of photovoltaic water pumping systems for horticultural crops irrigation: A guide to electrical energy potential assessment for increase access to electrical energy," J. Clean. Prod., vol. 238, 2019.

[15] W. Shao et al., "Evaluation of a photovoltaic water-supply scheme for the surface water system in Xiamen, China," Appl. Energy, vol. 230, pp. 357-373, Aug. 2018.

[16] M. Errouha, A. Derouich, B. Nahid-Mobarakeh, S. Motahhir, and A. El Ghzizal, "Improvement control of photovoltaic based water pumping system without energy storage,” Sol. Energy, vol. 190, pp. 319-328, Aug. 2019.

[17] A. de O. Ferreira, A. U. Brito, M. A. B. Galhardo, L. Ferreira, and W. N. Macêdo, "Modeling, control and simulation of a small photovoltaic-wind water pumping system without battery bank," Comput. Electr. Eng., vol. 84, 2020.

[18] S. El-Ghzizel, H. Zeggar, M. Tahaikt, F. Tiyal, A. Elmidaoui, and M. Taky, "Nanofiltration process combined with electrochemical disinfection for drinking water production: Feasibility study and optimization," J. Water Process Eng., vol. 36, Feb. 2020.

[19] M. Molinos-Senante and R. Sala-Garrido, "Energy intensity of treating drinking water: Understanding the influence of factors," Appl. Energy, vol. 202, pp. 275-281, Sep. 2017.

[20] Y. Sun et al., "Characteristics of water quality of municipal wastewater treatment plants in China: implications for resources utilization and management," J. Clean. Prod., vol. 131, pp. 1-9, Sep. 2016.

[21] M. Elyaqouti, L. Bouhouch, and A. Ihal, "Modelling and Predicting of the Characteristics of a Photovoltaic Generator on a Horizaontal and Tilted Surface," International Journal of Electrical and Computer Engineering (IJECE), vol. 6, no. 6, pp. 2257-2576, Dec. 2016.

[22] Amirullah and A. Kiswantono, "Power Quality Enhancement of Integration Photovoltaic Generator to Grid under Variable Solar Irradiance Level Using MPPT-Fuzzy," International Journal of Electrical and Computer Engineering (IJECE), vol. 6, no. 6, pp. 2629-2642, Dec. 2016.

M. Lal Azad, P. K. Sadhu, S. Das, B. Satpati, A. Gupta, P. Arvind, and R. Biswas, “An Improved Approach to Design a Photovoltaic Panel," Indonesian Journal of Electrical Engineering and Computer Science (IJEECS), vol. 5, no. 3, pp. 515-520, Mar. 2017.

[23] Syafii, R. Putra, and H. Putra, "Online Monitoring of Grid Connected Residential Photovoltaic System using Zigbee and Web Server," Indonesian Journal of Electrical Engineering and Computer Science (IJEECS), vol. 7, no. 3, pp. 668-675, Sep. 2017.

[24] A. Hassani, M. Maamoun, R. Tadrist, and A. Nesba, "A New High Speed and Accurate FPGA.based Maximum Power Point Tracking Method for Photovoltaic Systems," International Journal of Power Electronics and Drive Systems (IJPEDS), vol. 8, no. 3, pp. 1335-1344, Sep. 2017.

[25] J. Cunliang, W. Yanxiong, and W. Zerong, "Photovoltaic Array Maximum Power Point Tracking Based on Improved Method," TELKOMNIKA Telecommunication Computing Electronics and Control, vol. 14, no. 2, pp. 404-410, Jun. 2016.

[26] M. Satyanarayana and P. S. Kumar, "Analysis and Design of Solar Photovoltaic Grid Connected Inverter," Indonesian Journal of Electrical Engineering and Informatics (IJEEI), vol. 3, no. 4, pp. 199-208, Dec. 2015.

[27] C. Sharma and A. Jain, "Entrepreneurship Through Start-ups in Hill Areas Using Photovoltaic Systems," Bulletin of Electrical Engineering and Informatics (BEEI), vol. 6, no. 2, pp. 105-121, Jun. 2017. 